\title{
Pengembangan Media Pembelajaran Teka-Teki Silang (TTS) Pada Materi Sistem Gerak Untuk Kelas XI SMA
}

\author{
Maria Yuniati Nona Ade ${ }^{1) *}$, Yohanes Bare ${ }^{1)}$, Oktavius Yoseph Tuta Mago ${ }^{1)}$ \\ ${ }^{1)}$ Pendidikan Biologi, FKIP, Universitas Nusa Nipa Indonesia \\ *yunitakhajetanus@gmail.com
}

Abstrak: TTS merupakan salah satu media dengan ciri khas menggunakan soal yang mengasah otak, dengan ciri khas menjawab pertanyaan pada kotak-kotak mendatar dan menurun sehingga membentuk sebuah kata. Penelitian ini bertujuan untuk mengetahui tingkat validitas dan kelayakan dari media pembelajaran TTS pada materi sistem gerak kelas XI SMA. Penelitian ini dilaksanakan pada bulan September - Oktober 2021 di SMAS Katolik St. John Paul II Maumere. Jenis penelitian ini adalah Research and Development dengan model 4D. Subjek dalam penelitian ini, yaitu pada uji coba skala kecil dengan jumlah peserta didik 6 orang dan 1 orang pendidik biologi sedangkan pada uji coba skala besar melibatkan 30 peserta didik dan 1 orang pendidik biologi. Hasil penelitian menunjukan bahwa media pembelajaran TTS yang dikembangkan layak digunakan dalam pembelajaran biologi. Dapat dilihat pada tingkat validitas dari validator materi sebesar 88 , validator bahasa 93 dan validator media 88. Kelayakan media pembelajaran TTS pada uji coba skala kecil oleh pendidik diperoleh skor rerata 92 dalam kategori Sangat Layak dan peserta didik 69 di kategori Layak sedangkan hasil angket kelayakan media TTS pada uji coba skala besar oleh pendidik skor rerata 100 Sangat Baik dan peserta didik diperoleh skor rerata 82,93 dengan kategori Layak. Dengan adanya media pembelajaran TTS peserta didik lebih tertarik untuk belajar dan memahami materi sistem gerak. Media TTS pada materi sistem gerak sangat valid dan layak untuk digunakan dalam pembelajaran.

Kata Kunci: 4D Media Pembelajaran, Sistem Gerak, TTS

\section{Pendahuluan}

Kurikulum 2013 mendefinisikan pendidikan mempunyai peran dalam membantu meningkatkan sumber daya manusia (SDM) yang memiliki kualitas pendidikan secara nasional dan internasional dalam menjawab persaingan global (Hamalik, 2013; Hayong dan Putra, 2020; S dan Bare, 2019). Pendidik dituntut untuk melakukan berbagai inovasi di bidang pendidikan sehingga dapat mencapai tujuan dari pendidikan nasional. Salah satu inovasi dalam pendidikan tinggi adalah dengan pengembangan media pembelajaran. Guru profesional dituntut untuk sanggup memilih metode dan media pembelajaran yang tepat dalam proses pembelajaran. Guru terkadang sulit untuk memilih metode yang akan dipakai, serta menerapkan media pembelajaran yang sesuai. Hal ini akan berdampak pada prestasi belajar siswa (Ghiffary, 2019; Sizi et al., 2021).

Mata pelajaran biologi merupakan salah satu ilmu pengetahuan alam yang membimbing siswa untuk berperan aktif dalam belajar. Salah satu pokok bahasan pada mata pelajaran biologi yang dipelajari di kelas XI semester 1, yaitu Sistem Gerak. Pokok bahasan sistem gerak berisi materi tentang jenis-jenis rangka, tipe-tipe persendian, mekanisme kerja otot dan gangguan-gangguan pada sistem gerak. Dalam pembelajaran biologi terdapat beberapa materi salah satunya materi sistem gerak, materi pada KD 3.4 ini merupakan salah satu materi yang sulit dipahami karena banyak sekali jenis-jenis rangka, jenis-jenis otot, jenis-jenis persendian dan gangguan-gangguannya sehingga dirasakan lebih sulit dipelajari peserta didik (Ulfah, 2012).

Materi yang akan dipelajari bersifat hafalan dan membutuhkan pemahaman yang lebih tinggi, oleh karena itu diperlukan minat dan motivasi siswa untuk lebih berpartisipasi dalam proses pembelajaran agar siswa dapat memahami konsep yang diajukan. Minimnya minat dan motivasi peserta didik tersebut akan berdampak pada rendahnya prestasi akademik mereka (Meilina dan Widiyaningrum, 2016). Berdasarkan hasil observasi peneliti selama PPL di SMAS Katolik St. John Paul II Maumere, materi sistem gerak merupakan salah satu materi yang dianggap cukup sulit oleh peserta didik karena membutuhkan hafalan dan pemahaman 
dalam mempelajari jenis-jenis rangka, tipe-tipe persendian, mekanisme kerja otot dan gangguan-gangguan pada sistem gerak. Keadaan ini menyebabkan kurangnya minat peserta didik untuk mempelajari materi sistem gerak.

Peningkatan motivasi, pemahaman dan minat belajar pada materi sistem gerak perlu dikembangkan media pembelajaran. Salah satu media yang dapat digunakan untuk meningkatkan pemahaman siswa adalah permainan puzzle (Khairunnisa dkk, 2017). Pada media pembelajaran crossword puzzles (TTS) dilengkapi dengan kotak untuk menjawab soal yang dapat merangsang keingintahuan siswa untuk mencari dan menemukan jawaban dari setiap soal TTS yang diberikan. Keadaan ini dapat memudahkan siswa untuk memperoleh pengetahuan (Warningsih, 2019). Keunggulan TTS dikaji dari peneliti sebelumnya Ratnasari (2017), menunjukkan bahwa berdasarkan keefektifan dan peningkatan hasil belajar siswa, kartu teka-teki silang pada materi sel layak untuk pembelajaran. Penelitian Sugiharti dan Saputro (2013), dalam pembelajaran sistem periodik unsur kelas X di SMA Negeri 1 Karanganyar, penggunaan media teka-teki silang dapat meningkatkan prestasi belajar kognitif siswa. SMAS Katolik John Paul II Maumere belum menggunakan media pembelajaran berupa teka-teki silang. Sehingga peneliti tertarik untuk membuat sebuah media pembelajaran biologi berupa TTS. Media ini diharapkan dapat membantu peserta didik dalam mempelajari dan memahami materi dengan lebih mudah dan menyenangkan. Tujuan penelitian ini adalah Pengembangan media pembelajaran TTS pada materi sistem gerak untuk kelas XI SMA.

\section{Metode}

\section{Model Penelitian}

Dalam penelitian ini menggunakan metode penelitian dan pengembangan (Research $\mathcal{E}$ Development) atau lebih dikenal dengan $R \& D$ merupakan metode yang digunakan untuk menghasilkan produk tertentu dan menguji kelayakan produk tersebut (Aryani, 2012). Media pembelajaran teka-teki silang akan dikembangkan dengan model 4-D (four-D) dengan model pengembangan yang disesuaikan dengan kemampuan peneliti. Model pengembangan 4-D mengikuti alur dari Thiagarajan dkk., (1974). Pengembangan ini mengacu pada model 4D yang terdidri dari beberapa tahapan antara lain; tahap pendefenisian (Define), tahap perancangan (Design), tahap pengembangan (Development), tahap penyebaran (Disseminate).

\section{Subjek Penelitian}

Penelitian ini dilakukan pada peserta didik SMAS Katolik St. John Paul II Maumere. Subjek penelitian ini, yaitu peserta didik kelas XII. Uji tahap pertama (kelompok kecil) sebanyak 6 orang peserta didik dan 1 orang pendidik biologi. Untuk uji tahap kedua (kelompok besar) sebanyak 30 peserta didik dan 1 orang pendidik biologi. Teknik pengumpulan data dalam penelitian ini terdiri atas angket dan dokumentasi.

\section{Teknis Analisis Data}

Data yang diperoleh melalui instrumen penelitian selanjutnya diolah dan dianalisis.

\section{Data Analisis Validitas}

Data analisis validitas diperoleh dari data hasil penelitian yang dilakukan oleh ahli media, ahli materi, dan ahli bahasa. Data analisis validitas produk diolah dengan menggunakan persentase validitas. Penilaian untuk validitas dilakukan dengan menggunakan skala likert berupa data kuantitatif selanjutnya data dimasukan dalam kriteria validasi sesuai dengan penelitian Permatasari dan Wakhyudin, (2017).

\section{Data analisis Kelayakan}

Data analisis kelayakan berupa data kualitatif yang diperoleh pada saat uji coba produk berupa angket yang dibuat berdasarkan skala likert dan dilanjutkan kepada kategori sesuai dengan penelitian Adi, (2016).

Data hasil angket tentang penilaian kelayakan media pembelajaran biologi teka-teki silang dari pendidik pada uji coba skala kecil dan uji coba skala kelas besar kemudian diolah menjadi kategori penilaian kelayakan media. Kategori produk hasil penilaian kelayakan media oleh pendidik (Tabel 1).

Angket peserta didik dianalisis dan diolah menjadi kategori penilaian kelayakan media. Kategori produk hasil penilaian kelayakan media oleh peserta didik (Tabel 2). 
Tabel 1. Kategori Produk Hasil Penilaian Kelayakan oleh Pendidik

\begin{tabular}{ccc}
\hline No & Rentang Skor & Kategori \\
\hline 1 & $\mathrm{X}>104,88$ & Sangat Layak \\
2 & $84,98<\mathrm{X} \leq 104,88$ & Layak \\
3 & $65,04<\mathrm{X} \leq 84,98$ & Cukup Layak \\
4 & $45,12<\mathrm{X} \leq 65,4$ & Kurang Layak \\
5 & $\mathrm{X} \leq 45,12$ & Sangat Kurang Layak \\
\hline
\end{tabular}

Tabel 2. Kategori Produk Hasil Penilaian Kelayakan Media oleh Peserta Didik

\begin{tabular}{ccc}
\hline No & Rentang Skor & Kategori \\
\hline 1 & $\mathrm{X}>83,94$ & Sangat Layak \\
2 & $67,98<\mathrm{X} \leq 83,94$ & Layak \\
3 & $52,02<\mathrm{X} \leq 67,98$ & Cukup Layak \\
4 & $36,06<\mathrm{X} \leq 52,02$ & Kurang Layak \\
5 & $\mathrm{X} \leq 36,06$ & Sangat Kurang Layak \\
\hline
\end{tabular}

\section{Hasil dan Pembahasan}

\section{Deskripsi Hasil Penelitian}

Penelitian dan pengembangan media pembelajaran teka-teki silang pada materi sistem gerak dilaksanakan di kelas XI MIA 1 SMAS Katolik St. John Paul II Maumere.

\section{Pendefinisian TTS pada materi sistem gerak}

Tahap pertama dalam penelitian ini, yaitu pendefinisian. Tahap pendefinisian meliputi:

Analisis Awal Akhir

Analisis awal akhir meliputi analisis kurikulum yang berlaku dan sesuai dengan materi pada kompetensi dasar. Kurikulum yang digunakan di SMAS Katolik St. John Paul II Maumere yaitu kurikulum 2013.

Analisis Peserta Didik

Analisis peserta didik dilakukan sebelum penelitian dilakukan dengan cara melihat karakteristik dasar peserta didik dan kemampuan awal. Berdasarkan wawancara dengan pendidik biologi di SMA, yaitu rendahnya kemampuan peserta didik dalam memahami materi sistem gerak yang merupakan salah satu materi yang dianggap cukup sulit oleh peserta didik. Proses pembelajaran pendidik harus menggunakan media pembelajaran yang dapat menumbuhkan semangat belajar peserta didik. Solusi terhadap permasalah tersebut dengan menerapkan media yang tepat salah satunya media pembelajaran TTS.

Analisis Tugas

Analisis tugas terdiri dari analisis terhadap standar kompetensi dan kompetensi dasar yang terkait pada materi sistem gerak yang dikembangkan pada media TTS. Berdasarkan materi sistem gerak dirumuskan standar kompetensinya yaitu Memahami, menerapkan, menganalisis dan mengevaluasi pengetahuan faktual, konseptual, prosedural, dan metakognitif berdasarkan rasa ingin tahunya tentang ilmu pengetahuan, teknologi, seni, budaya, dan humaniora dengan wawasan kemanusiaan, kebangsaan, kenegaraan, dan peradaban terkait penyebab fenomena dan kejadian, serta menerapkan pengetahuan prosedural pada bidang kajian yang spesifik sesuai dengan bakat dan minatnya untuk memecahkan masalah. Kompetensi dasarnya yaitu menganalisis hubungan antara struktur jaringan penyusun organ pada sistem gerak dalam kaitannya dengan bioproses dan gangguan fungsi yang dapat terjadi pada sistem gerak manusia.

Analisis Tujuan

Perumusan tujuan pembelajaran merupakan dasar untuk mendesain perangkat pembelajaran dan penyusunan tes. Rumuskan tujuan pembelajaran dari materi sistem gerak yaitu menganalisis hubungan antara struktur jaringan penyusun organ pada sistem gerak dalam kaitannya dengan bioproses dan gangguan fungsi 
yang dapat terjadi pada sistem gerak manusia, sehingga, peserta didik dapat menghayati dan mengamalkan ajaran agama yang dianutnya melalui belajar biologi, mengembangakan sikap jujur, peduli, dan bertanggung jawab, serta dapat mengembangkan kemampuan berpikir kritis, komunikasi, kolaborasi, kreativitas (4C).

\section{Perancangan TTS pada materi sistem gerak}

Tahap ini merupakan tahap untuk merancang sebuah media TTS yang dapat digunakan dalam pembelajaran biologi di SMAS Katolik St. John Paul II Maumere. Pada penelitian ini tahap perancangan terdiri dari:

\section{Pemilihan Media}

Media pembelajaran yang digunakan peserta didik untuk proses pembelajaran pada materi sistem gerak yaitu media TTS. Peneliti mengembangkan media TTS dengan menggunakan sumber dari buku kurikulum 2013.

\section{Pemilihan Format}

Pada tahap ini peneliti memilih format untuk mendesain isi dan pemilihan strategi pembelajaran yang sesuai. Pemilihan strategi pembelajaran disesuaikan kurikulum 2013, dengan menggunakan pendekatan saintifik yang terdiri dari $5 \mathrm{M}$ yaitu mengamati, menanya, menalar, mencoba dan mengkomunikasikan. Berdasarkan pandangan tersebut maka format media TTS yang dikembangkan dalam penelitian ini adalah bagian awal, bagian isi, kotak-kotak TTS dan bagian akhir dengan jenis hurufnya kolektif dan oregano, spasi 1,4 dengan desain berupa gambar-gambar yang diperoleh dari internet.

\section{Desain Awal}

Desain awal merupakan rancangan media pembelajaran TTS yang telah dibuat oleh peneliti menggunakan beberapa aplikasi seperti postermywall untuk pembuatan cover, discovery puzzlemaker membuat kotak-kotak pada media TTS dan aplikasi Canva untuk pembuatan format desain TTS.

1) Penentuan Judul Teka Teki Silang

TTS yang dikembangkan di beri judul "sistem gerak"

2) Halaman Sampul

Cover merupakan halaman depan dari sebuah TTS yang terdiri atas judul TTS, gambar ilustrasi materi dalam TTS (Gambar 1).

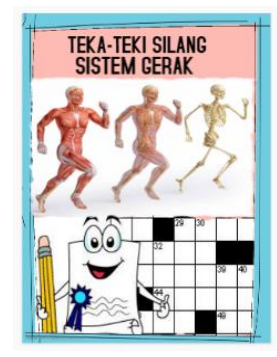

Gambar 1. Tampilan Cover Depan

Background pada TTS adalah gambar sistem gerak pemanfaatkan gambar ini karenakan materi yang akan dibahas pada media ini adalah sistem gerak. Kemudian terdapat gambar ilustrasi dan kotak-kotak tekateki silang merupakan gambar yang mewakili media yang akan dikembangkan yaitu teka-teki silang.

\section{3) Kata Pengantar}

Kata pengantar terdiri atas tiga paragraf. Paragraf pertama berisikan ucapan syukur terhadap penyelesaian TTS ini dan pendeskripsian materi yang terdapat pada media pembelajaran ini, paragraf kedua menjelaskan permintaan dari penulis untuk memberikan saran dan kritikan terhadap media yang di kembangkan. Paragraf terakhir berisikan ucapan terima kasih terhadap semua pihak yang membantu dalam menyelesaikan TTS. 
4) Daftar Isi

Bagian ini menginformasikan kepada pengguna tentang topik-topik yang akan ditampilkan dalam media TTS sesuai urutan yang terdiri dari cover, kata pengantar, daftar isi, kompetensi inti, kompetensi dasar dan IPK, peta konsep, glosarium, info biologi 1, latihan 1, info biologi 2, latihan biologi 2, info biologi 3, latihan 3, daftar pustaka, dan biodata penulis.

5) Kompetensi Inti

Kompetensi inti diturunkan dari rumusan kurikulum 2013. Terdapat dua kompetensi inti yang diperoleh yaitu:

KI 3: Memahami, menerapkan, menganalisis dan mengevaluasi pengetahuan faktual, konseptual, prosedural, dan metakognitif berdasarkan rasa ingin tahunya tentang ilmu pengetahuan, teknologi, seni, budaya, dan humaniora dengan wawasan kemanusiaan, kebangsaan, kenegaraan, dan peradaban terkait penyebab fenomena dan kejadian, serta menerapkan pengetahuan prosedural pada bidang kajian yang spesifik sesuai dengan bakat dan minatnya untuk memecahkan masalah.

KI 4: Mengolah, menalar, menyaji, dan mencipta dalam ranah konkret dan ranah abstrak terkait dengan pengembangan dari yang dipelajarinya di sekolah secara mandiri serta bertindak secara efektif dan kreatif, dan mampu menggunakan metoda sesuai kaidah keilmuan.

6) Kompetensi Dasar dan IPK

Kompetensi dasar bertujuan untuk mencapai kompetensi inti yang harus diperoleh siswa melalui pembelajaran. Adapun Indikator Pencapaian kompetensi diturunkan dari KD yang harus dicapai siswa dalam kegiatan pembelajaran (Gambar 2).

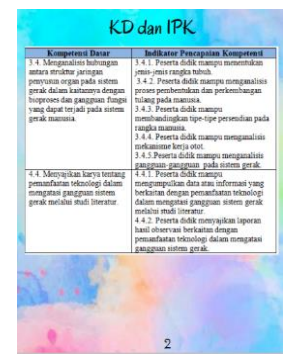

\section{Gambar 2. Tampilan KD dan IPK}

Kompetensi inti ini diambil dari buku paket biologi kelas XI. Sedangkan indikator pencapaian kompetensi dibuat oleh penulis disesuaikan dengan kompetensi dasar yang akan dicapai oleh peserta didik.

7) Peta Konsep

Peta konsep merupakan gambaran dari isi materi sistem gerak yang dirancang dalam media TTS (Gambar 3).

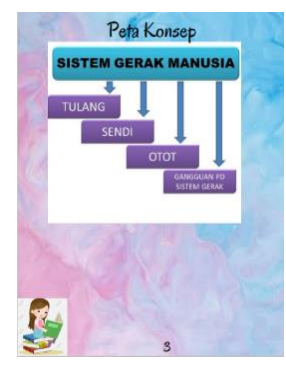

Gambar 3. Tampilan Peta Konsep

Isi dari materi pada peta konsep ini yaitu tulang, sendi, otot dan gangguan pada sistem gerak. Background yang digunakan berwarna putih, biru dan merah muda sera terdapat gambar ilustrasi membaca buku ini bertujuan agar tampilan dari peta konsep ini lebih menarik. 
8) Glosarium

Memuat daftar kata dengan penjelasannya. Glosarium disusun berdasarkan alphabet (Gambar 4). Glosarium yang disajikan agar dapat memudahkan peserta didik dalam memahami istilah yang cukup sulit.

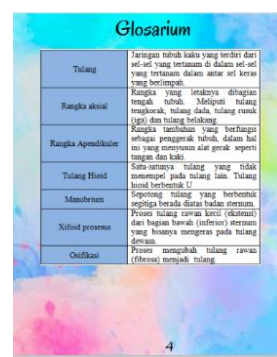

Gambar 4. Tampilan Glosarium

Istilah-istilah yang terdapat pada glosarium yaitu tulang, rangka aksial, rangka apendikular, tulang hioid, manubrium, xifoid process, dan osifikasi. Istilah-istilah glosarium ini dibuat dalam bentuk tabel dengan tujuan agar lebih rapi dan mudah dibaca.

9) Info Biologi

Merupakan informasi yang berkaitan dengan materi sistem gerak. Info biologi disusun untuk menambah pengetahuan peserta didik (Gambar 5).
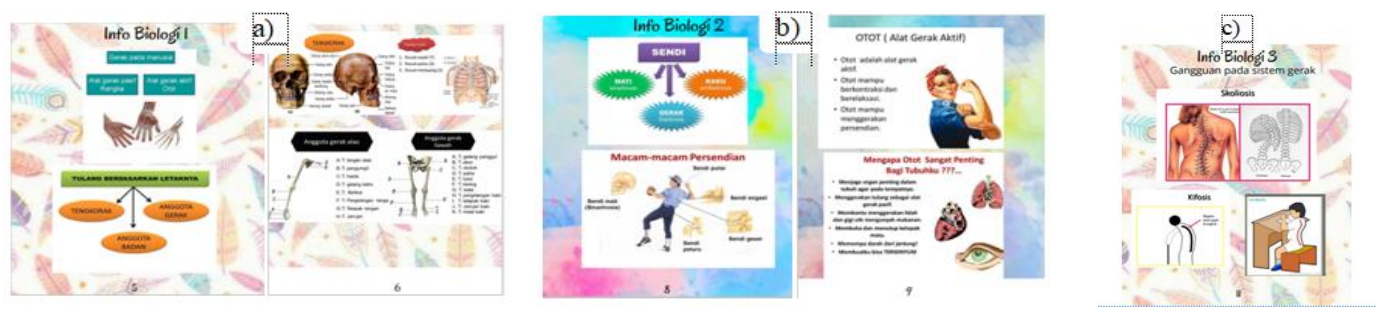

Gambar 5. Tampilan Info Biologi a). Info Biologi, b). Info Biologi 2, c). Info Biologi 3

Pada info biologi dibagi menjadi 3 yaitu info biologi 1 yang membahas tentang tulang dan pembagian tulang berdasarkan letaknya serta bagian-bagian pada tulang yang terdiri dari tulang tengkorak, tulang rusuk, anggota gerak atas dan anggota gerak bawah. Pada info biologi 2 pembahasan tentang sendi, macam persendian, otot dan manfaat otot bagi tubuh. Sedangkan pada info biologi 3 membahas materi gangguan yang terdapat pada sistem gerak. Pada ketiga info biologi ini juga terdapat gambar-gambar sebagai pendukung materi sistem gerak.

10)Latihan

Memuat soal-soal yang akan dikerjakan untuk melatih kemampuan peserta didik terhadap materi sistem gerak di setiap pertemuan (Gambar 6).
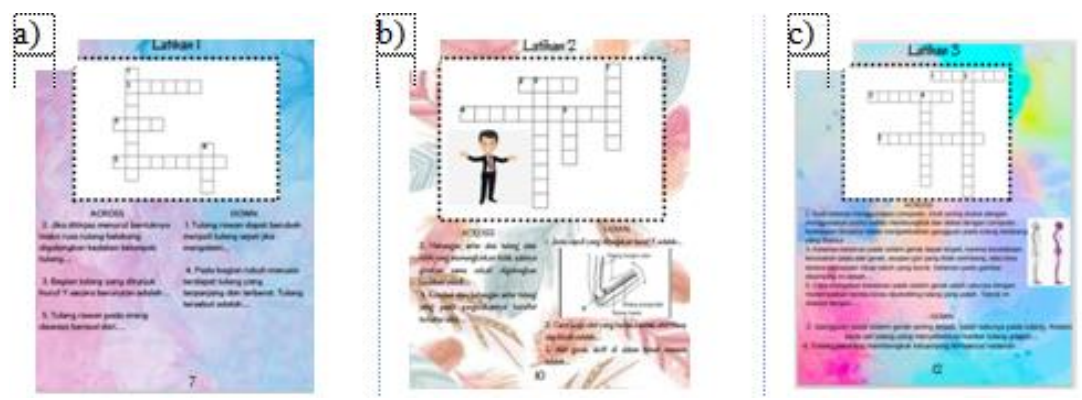

Gambar 6. Tampilan Latihan pada Media TTS a). Latihan 1, b). Latihan 2, dan c). Latihan 3.

Pada latihan ini dibagi menjadi 3 bagian yaitu latihan 1 memuat soal-soal yang berkaitan dengan tulang, latihan 2 terdapat soal-soal yang berkaitan dengan sendi dan otot sedangkan pada latihan 3 memuat soal soal yang berhubungan dengan sistem gerak. 
11)Daftar Pustaka

Pada daftar pustaka memuat sejumlah reverensi yang digunakan sebagai bahan rujukan ditulis. Daftar pustaka yang digunakan penulis terdiri dari dua yang diambil dari buku kurikulum 2013.

12)Biodata Penulis

Biodata penulis memuat identitas dan riwayat singkat pendidikan penulis (Gambar 7).

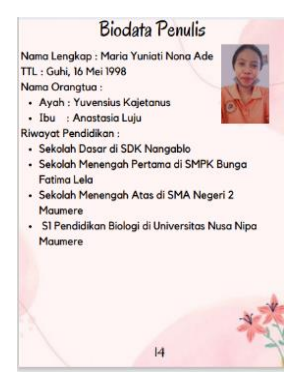

Gambar 7. Tampilan Biodata Penulis

Biodata penulis terdiri dari nama lengkap, tempat tanggal lahir, nama orangtua, riwayat pendidikan dan foto dari penulis. Pada biodata ini juga terdapat foto penulis.

\section{Pengembangan TTS pada materi sistem gerak}

Tahap develop (pengembangan), mencakup proses pembuatan media pembelajaran TTS pada materi sistem gerak, validasi, revisi tahap pertama sampai menghasilkan produk yang siap untuk diujikan. Tahaptahap pengembangan media pembelajaran TTS sebagai berikut:

\section{Validasi Ahli}

Teka-teki silang setelah direvisi kemudian diberikan kepada ahli materi, ahli media dan ahli bahasa untuk divalidasi agar dapat mengetahui media TTS yang telah dikembangkan layak digunakan. Media pembelajaran TTS selesai dikembangkan, tahap selanjutnya berupa validasi produk media pembelajaran TTS.

\section{Validasi Materi}

Validator materi melakukan validasi terhadap isi atau konten materi pada media pembelajaran yang dikembangkan. Jumlah pernyataan yang dinilai oleh validator materi sebanyak 10 pernyataan. Beberapa saran yang diberikan oleh validator materi yaitu Kompetensi Inti sebaiknya ditulis dari KI-1 sampai KI-4, soal-soal diperbanyak lagi agar lebih menambah wawasan peserta didik (Tabel 3).

Tabel 3. Revisi dan Hasil Revisi Berdasarkan Ahli Materi

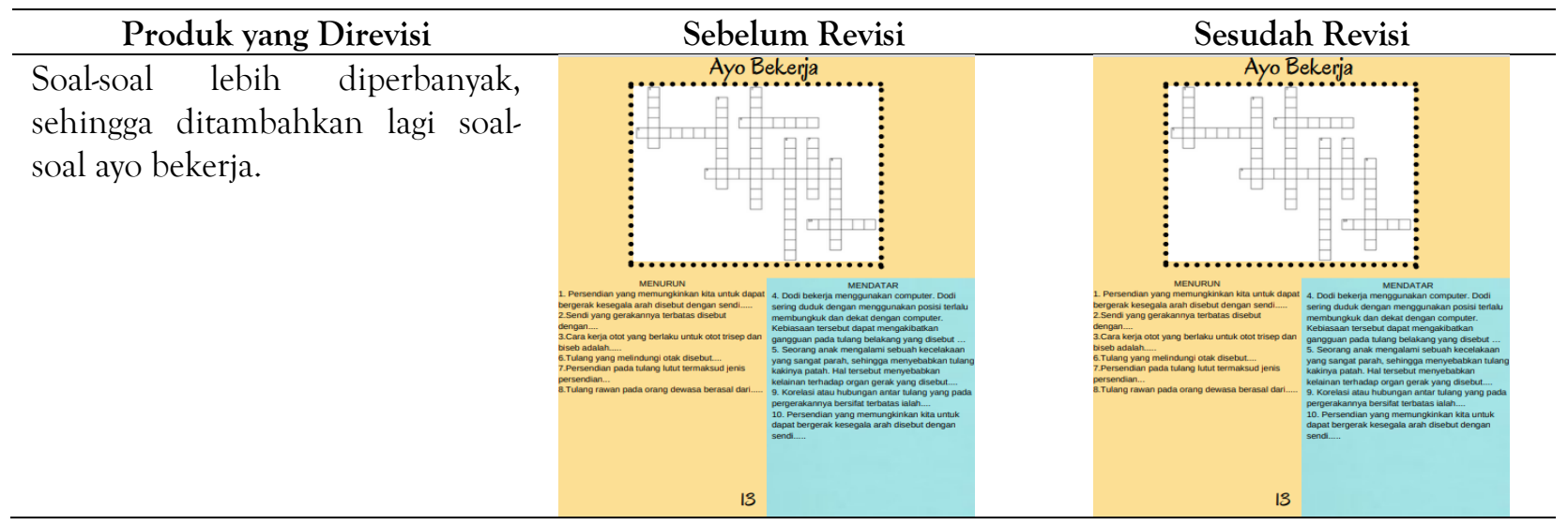

\section{Validator Bahasa}

Validator bahasa melakukan validasi terhadap tata bahasa dan tulisan pada media pembelajaran yang dikembangkan dengan jumlah 10 pernyataan. Saran yang diberikan oleh validator bahasa yaitu pada daftar isi tidak terdapat halaman dan nomor halaman, penulisan Across atau down sebaiknya berbahasa indonesia, 
karena soal berbahasa indonesia, penulisan tempat tanggal lahir pada biodata penulis sebaiknya ditulis lengkap jangan disingkat (Tabel 4).

Tabel 4. Revisi dan Hasil Revisi Ahli Bahasa

\begin{tabular}{lll}
\hline \multicolumn{1}{c}{ Produk yang Direvisi } & Sebelum Revisi \\
\hline Penulisan (Across/down) sebaiknya & Sesudah Revisi \\
berbahasa indonesia, karena soal \\
berbahasa indonesia.
\end{tabular}

Validator Media

Validator media melakukan validasi terhadap media pembelajaran yang dikembangkan dengan jumlah pernyataan sebanyak 10 . Validasi yang dilakukan oleh validator materi mendapatkan beberapa saran perbaikan yaitu background yang digunakan jangan terlalu banyak variasi (Tabel 5).

Tabel 5. Revisi dan Hasil Revisi Ahli Media

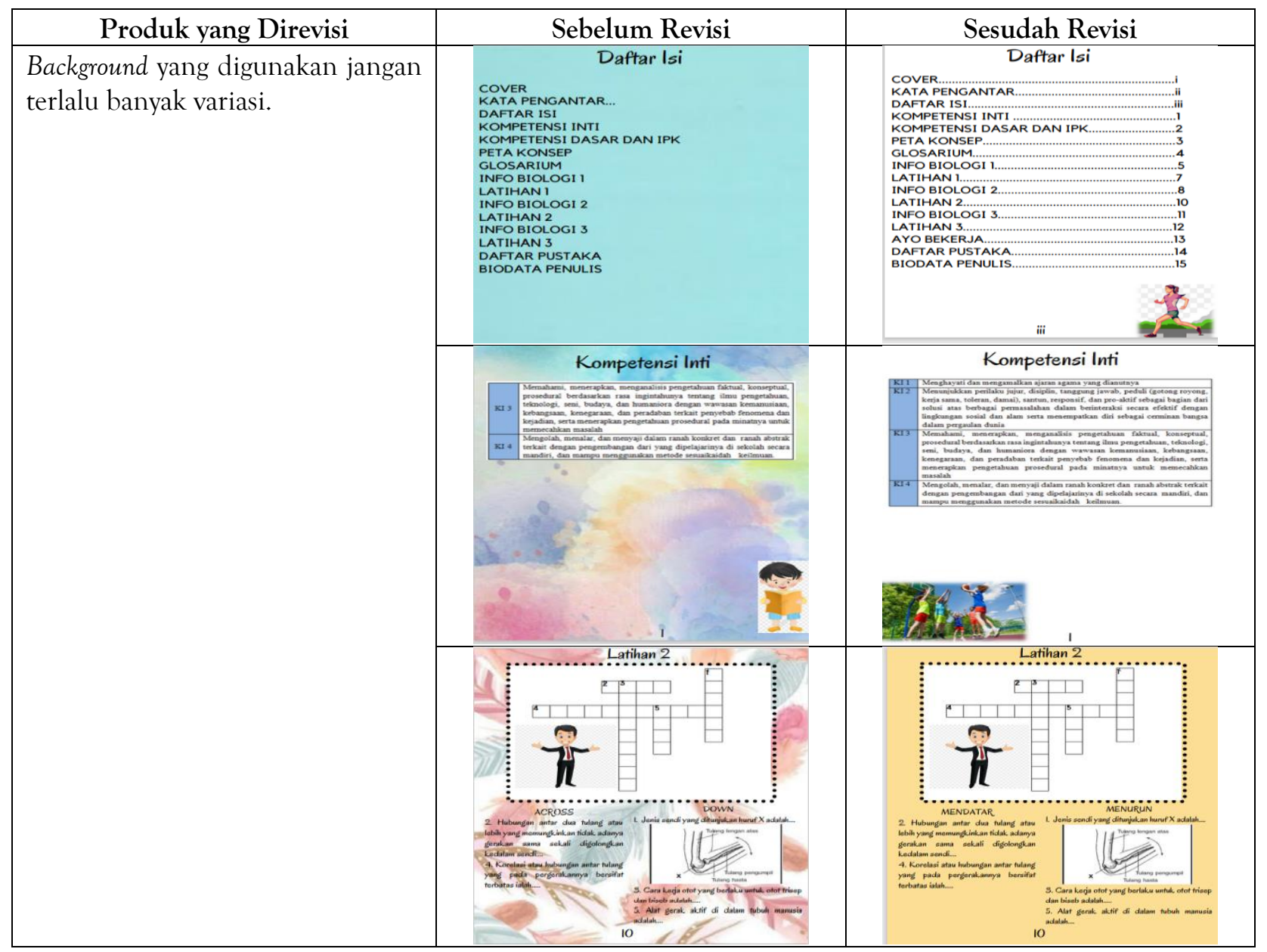




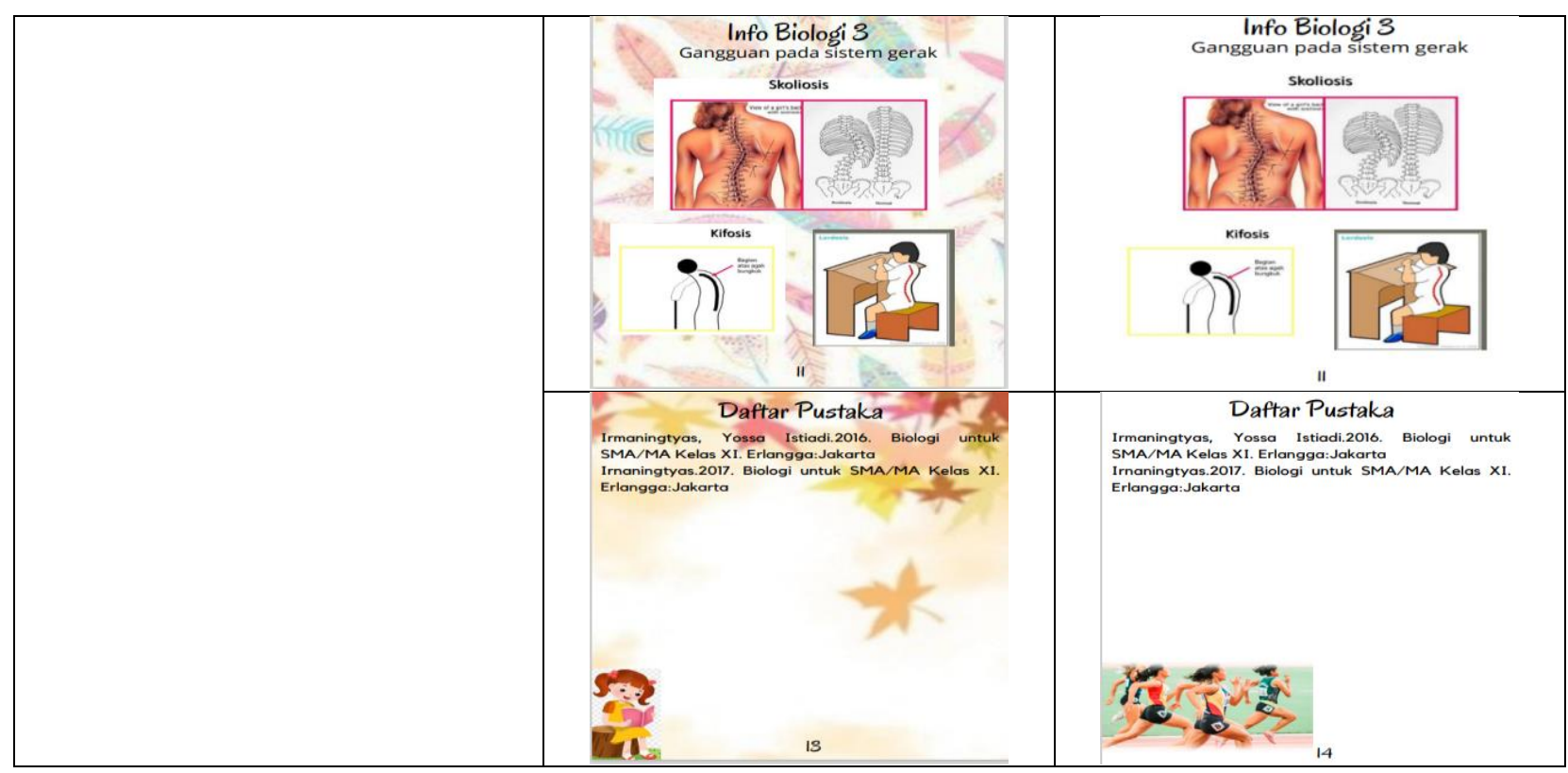

Media dikatakan valid atau layak digunakan apabila diperoleh tingkat persentase validitas tinggi, sedangkan sebaliknya dikatakan tidak valid jika tingkat validitasnya rendah (Tabel 6).

Tabel 6. Data Hasil Validasi Oleh Validator

\begin{tabular}{ccccc}
\hline No & Validator & Data Hasil Validasi & Rata-rata & Tingkat Validitas \\
\hline 1 & Materi (1) & 82 & 88 & Sangat Valid \\
2 & Materi (2) & 94 & & \\
3 & Bahasa (1) & 98 & 93 & Sangat Valid \\
4 & Bahasa (2) & 88 & & \\
5 & Media (1) & 86 & 88 & Sangat Valid \\
6 & Media (2) & 90 & & \\
\hline
\end{tabular}

Berdasarkan tabel 6 dapat disimpulkan bahwa penilaian yang diberikan oleh para ahli dari ahli materi, ahli media dan ahli bahasa produk yang dikembangkan memenuhi kriteria "sangat valid". Selain memberikan penilaian para ahli memberikan masukan serta saran untuk memperbaiki produk yang dikembangkan, sehingga dapat digunakan untuk melakukan uji coba produk di kelas kecil. Hal ini didukung oleh penelitian dari Wirani, (2018) dimana hasil validasi media oleh ahli materi sebesar $80 \%$ yang dinyatakan layak dan berdasarkan validasi media diperoleh 92,5\% yang dinyatakan sangat layak. Penelitian Ndia et al., (2021) menyatakan bahwa nilai kevalidan produk berpengaruh terhadap implementasi produk di uji skala kecil maupun skala besar. Media pembelajaran yang dikembangkan dengan validitas yang tinggi dapat berpengaruh terhadap hasil hasil belajar siswa (Bare et al., 2021; Hayong \& Putra, 2020; S \& Bare, 2019b). Penelitian ini juga didukung oleh Cahyaningsih dan Sulistiyawati, (2021) media TTS sistem regulasi berdasarkan penilaian dari seluruh reviewer yaitu para ahli, guru dan peer-reviewer memperoleh persentase keidealan sebesar $87,74 \%$ yang termasuk dalam kategori sangat baik untuk digunakan sebagai bentuk latihan soal biologi. Penelitian dari Aspriyani dan Suzana, (2020); Devianti dkk., (2017); Rete dkk., (2019) dimana hasil validasi media TTS yang dikembangkan dinyatakan sangat Valid.

\section{Kelayakan TTS}

\section{Uji Coba Skala Kecil}

Produk media pembelajaran TTS pada materi sistem gerak kelas XI yang sudah divalidasi kemudian diuji cobakan pada uji lapangan awal (uji coba skala kecil) dengan melibatkan 6 orang peserta didik kelas XI dan 1 orang pendidik. Uji coba skala kecil ini dilakukan dengan memberikan angket kelayakan produk media pembelajaran TTS yang bertujuan untuk memperoleh saran dan pendapat mengenai kegiatan-kegiatan dalam media pembelajaran TTS sebagai penyempurnaan produk media pembelajaran TTS pada materi sistem gerak. Saran yang diberikan dari uji coba skala kecil yaitu pada info biologi 1 ukuran huruf terlalu kecil, dan pada info biologi 3 penulisan lordosis tidak jelas (Tabel 7). 
Tabel 7. Revisi dan Hasil Revisi pada Skala Kecil

\begin{tabular}{|l|l|}
\hline Sebelum Perbaikan & Setelah Perbaikan \\
\hline Huruf tidak \\
warna putih.
\end{tabular}

Hasil uji coba skala kecil diperoleh rerata skor untuk peserta didik sebesar 69 dan dikategorikan layak, sedangkan rerata skor penilaian dari pendidik sebesar 92 dan dikategori sangat layak. Analisis data hasil uji coba skala kecil dalam penelitian ini bertujuan untuk mengetahui kelayakan media pembelajaran TTS yang dikembangkan (Tabel 8).

Tabel 8. Analisis Data Hasil Uji Coba Skala Kecil

\begin{tabular}{cccc}
\hline No & Subjek Uji Coba & Rata-Rata & Kategori \\
\hline 1 & 1 Orang Pendidik biologi & 92 & Sangat Layak \\
2 & 6 orang Peserta Didik XI MIA 1 & 69 & Layak \\
\hline
\end{tabular}

Penelitian dan pengembangan ini didukung dengan hasil penelitian yang dilakukan oleh beberapa peneliti diantaranya penelitian yang dilakukan oleh Sulfia dan Habibati, (2018) tentang penerapan media tekateki silang pada materi koloid untuk meningkatkan hasil belajar peserta didik, dimana tanggapan peserta didik terhadap media TTS memberikan respon positif yaitu sebesar 92,27\%. Nilai keyakan kelas kecil akan memberikan masukan dalam pengembangan kelas besar (Bare \& Sari, 2021; Ule et al., 2021, Pada et al, 2021).

\section{Uji Coba Skala Besar}

Produk media pembelajaran TTS pada materi sistem gerak yang sudah direvisi kemudian diuji cobakan pada uji coba lapangan skala besar. Saran dari uji coba skala besar sebagai masukan perbaikan produk media pembelajaran TTS materi sistem gerak digunakan untuk penyempurnaan akhir media pembelajaran TTS yang dikembangkan. Saran dan tanggapan dari uji coba skala besar yaitu pada daftar pustaka jarak penulisan antar pustaka harus ditulis ganda. Hasil penilaian uji kelayakan media pada uji lapangan skala besar (Tabel 9). 
Tabel 9 Revisi dan Hasil Revisi pada Skala Besar

\begin{tabular}{|c|c|}
\hline Sebelum di perbaiki & Sesudah diperbaiki \\
\hline 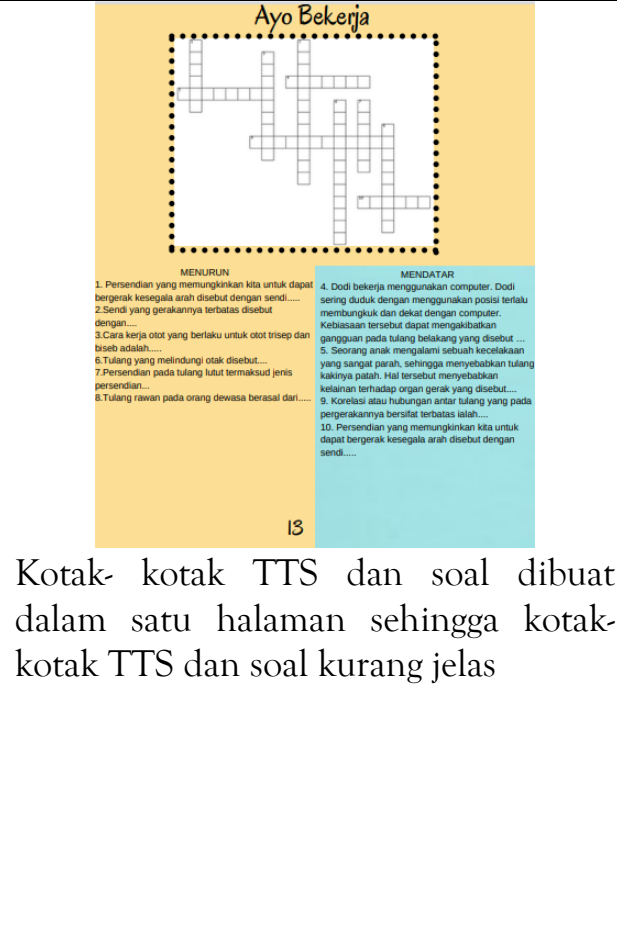 & 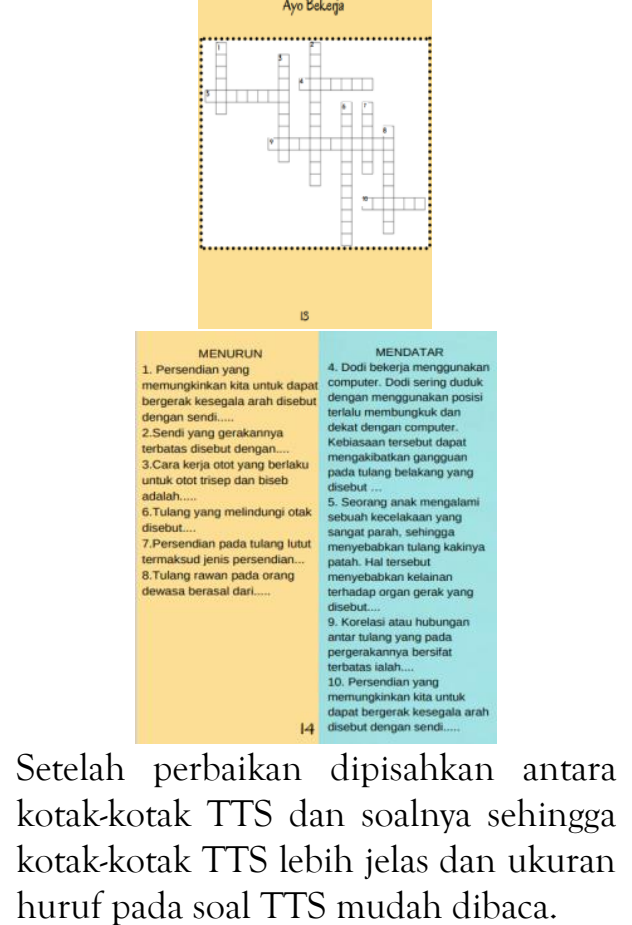 \\
\hline
\end{tabular}

Hasil analisis produk berdasarkan uji coba skala besar (Tabel 10).

Tabel 10 Hasil Analisis Data pada Uji Coba Skala Besar

\begin{tabular}{cccc}
\hline No & Subjek Uji Coba & Rata-Rata & Kategori \\
\hline 1 & 1 Orang Pendidik Biologi & 100 & Sangat Layak \\
2 & 30 Orang Peserta Didik MIA 1 & 82,93 & Layak \\
\hline
\end{tabular}

Hasil analisis data uji coba skala besar diperoleh rerata skor penilaian untuk peserta didik sebesar 82,93 dan dikategorikan layak, sedangkan rerata skor penilaian dari pendidik biologi sebesar 100 dikategorikan sangat layak. Hal ini didukung dengan hasil penelitian yang telah dilakukan oleh (Setiawati, 2018) dimana persentase respons peserta didik terhadap media teka-teki silang menunjukkan 88,60\% dari keseluruhan peserta didik, di kategori sangat layak.

\section{Penyebaran TTS pada materi sistem gerak}

Pada tahap ini dilakukan tahap penyebaran terbatas di sekolah penelitian, dengan memberikan produk kepada 1 orang pendidik biologi kelas XI di SMAS Katolik St. John Paul II Maumere. Pada tahap ini hanya dilakukan penyebaran terbatas karena keterbatasan media TTS yang disediakan oleh peneliti sehingga hanya diberikan kepada 1 orang pendidik biologi

\section{Simpulan}

Berdasarkan hasil penelitian Media pembelajaran TTS materi sistem gerak yang dikembangkan dinyatakan valid dan layak untuk diimplementasikan di kelas XI di SMAS Katolik St. John Paul II Maumere.

\section{Daftar Pustaka}

Adi, C. H. (2016). Pengembangan Film Animasi Sub-Tema Pengertian Dan Jenis Lembaga Sosial Untuk Mata Pelajaran IPS SMP Kelas VII. 5(7).

Aryani, L. (2012). Pengembangan Modul Berbasis Kurikulum 2013 pada Mata Pelajaran Administrasi Sarana dan Prasarana Kelas XI APK di SMK PGRI 2 Sidoarjo. 1(1), Surabaya. 
Aspriyani, R., \& Suzana, A. (2020). Pengembangan Modul Matematika Berbasis Brain Based Learning Menggunakan Permainan Teka-Teki Silang Pada Materi Barisan Dan Deret Geometri. Jurnal Penelitian Pembelajaran Matematika, 13(1).

Bare, Y., Putra, S. H. J., Bunga, Y. N., Mago, O. Y. T., S, M., \& Boli, Y. T. (2021). Implementasi Biology Club I di SMA Karitas Watuneso, Kecamatan Lio Timur, Kabupaten Ende. Jurnal ABDINUS: Jurnal Pengabdian Nusantara, 4(2), 321-328. https://doi.org/10.29407/ja.v4i2.15286

Bare, Y., \& Sari, D. R. T. (2021). Pengembangan Lembar Kerja Mahasiswa (LKM) Berbasis Inkuiri Pada Materi Interaksi Molekuler. BioEdUIN, 11(1), 8. https://doi.org/10.15575/bioeduin.v11i1.12077

Cahyaningsih, A., \& Sulistiyawati. (2021). Pengembangan Teka-Teki Silang (TTS) Sistem Regulasi sebagai Bentuk Latihan Soal Biologi. Jurnal Of Biological Education, 1(1), 9.

Devianti, D., Sudarti, \& P, S. H. B. (2017). Studi Literatur Pengembangan Modul Pembelajaran Fisika Berbasis Permainan Edukatif Teka-Teki Silang (TTS) DI SMA. Seminar Nasional Pendidikan Fisika, 2.

Ghiffary, M. (2019). Keefektifan Game Kuis TTS Pintar sebagai Media Pembelajaran Mata Pelajaran IPA Terpadu di SMP Islam Cahaya Insani Semarang. Universitas Negeri Semarang.

Hamalik, O. (2013). Kurikulum dan Pembelajaran. Bumi Aksara.

Hayong, M. S. W., \& Putra, S. H. J. (2020). Pengembangan Lembar Kerja Peserta Didik (LKPD) Berbasis Inkuiri Pada Materi Sistem Reproduksi Manusia Kelas XI SMA Development of Inquiry-Based Students' Worksheet on Human Reproductive System Subject for 11th Grade Senior High School. Spizaetus: Jurnal Biologi dan Pendidikan Biologi, 1(3), 38-49.

Khairunnisa, Saadi, P., \& Leny. (2017). Pengembangan Media Pembelajaran "Buku Teka-Teki Kimia” Untuk Kelas XI SMA. Journal of Chemistry And Education, 1(1), 5.

Meilina, D. F., \& Widiyaningrum, P. (2016). Efektivitas Pembelajaran Learning Cycle 5E Dipadu Dengan Media Puzzle Education Pada Materi Sistem Gerak Manusia Di SMA. Unnes.J.Biol.Educ., 5(1), 6.

Ndia, F. X., Mago, O. Y. T., \& Bare, Y. (2021). Pengembangan Lembar Kerja Peserta Didik (LKPD) Koopertif Tipe Jigsaw Materi Klasifikasi Makhluk Hidup Kelas VII SMP. Quagga: Jurnal Pendidikan Dan Biologi, 13(2), 24-30. https://doi.org/10.25134/quagga.v13i2.4011

Pada, K., Bare, Y., \& Putra, S. H. (2021). Pengembangan Lembar Kerja Peserta Didik (LKPD) Biologi Berbasis Pendekatan Scientific Materi Sistem Ekskresi Pada Manusia Kelas VIII SMP Negeri 2 Maumere. Jurnal Ilmiah Wahana Pendidikan, 7(8), 337-349. https://doi.org/10.5281/zenodo.5769603

Permatasari, R. R. N., \& Wakhyudin, H. (2017). Pengembangan Media Misugi Anaya Pada Pembelajaran IPA Materi Sumber Energi Dan Kegunaannya. 10.

Ratnasari, L. (2017). Pengembangan Kartu Permainan Teka-Teki Silang (TTS) untuk Meningkatkan Hasil Belajar Siswa Pada Materi Sel Kelas XI SMA. Bioedu Berkala Ilmia Pendidikan Biologi, 6(2), 7.

Rete, A., Nirmalasari, M. A. Y., \& Ware, K. (2019). Pengembangan Media Pembelajaran TTS Kimia Pada Materi Tata Nama Senyawa. SPIN (Jurnal Pendidikan Kimia), 1(1).

S, M., \& Bare, Y. (2019a). Meningkatkan Hasil Belajar Siswa pada Konsep Perubahan dan Pelestarian Lingkungan Hidup dengan Model Discovery Learning di SMAS Katolik ST Gabriel Maumere. BIOEDUSCIENCE: Jurnal Pendidikan Biologi dan Sains, 3(2), 84-89. https://doi.org/10.29405/j.bes/3284-893298

S, M., \& Bare, Y. (2019b). Meningkatkan Hasil Belajar Siswa pada Konsep Perubahan dan Pelestarian Lingkungan Hidup dengan Model Discovery Learning di SMAS Katolik ST Gabriel Maumere. BIOEDUSCIENCE: Jurnal Pendidikan Biologi dan Sains, 3(2), 84-89. https://doi.org/10.29405/j.bes/3284-893298

Setiawati, B. (2018). Pengembangan Teka-Teki Silang Sebagai Model Soal Kreativitas. 2(2), 8. 
Sizi, Y., Bare, Y., \& Galis, R. (2021). Pengaruh Model Pembelajaran Kooperatif Tipe Talking Stick Terhadap Keaktifan dan Hasil Belajar Kognitif Peserta Didik SMP Kelas VIII. Spizaetus: Jurnal Biologi dan Pendidikan Biologi, 2(1), 8.

Sugiharti, S., \& Saputro, S. (2013). Studi Komparasi Penggunaan Media TTS dan LKS pada Pembelajaran Kooperatif Studen Teams Achievement Divisions (STAD) pada Materi Pokok Sistem Periodik Unsur Kelas X Semester Gasal SMA Negeri 1 Karanganyar Tahun Pelajaran 2012/2013. 2(1), 7.

Sulfia, U., \& Habibati, H. (2018). Penerapan Media Teka-Teki Silang Pada Materi Koloid Untuk Meningkatkan Hasil Belajar Peserta Didik. Jurnal IPA \& Pembelajaran IPA, 1(1), 6-15. https://doi.org/10.24815/jipi.v1i1.9457

Thiagarajan, S., Semmel, D., \& Semmel, M. (1974). Instructional Development for Training Teachers of Exceptional Children: A Sourcebook. Indiana University.

Ule, K. N., Bunga, Y. N., \& Bare, Y. (2021). Pengembangan Modul Pembelajaran Biologi Berbasis Jelajah Alam Sekitar (JAS) Materi Ekosistem Taman Nasional Kelimutu (TNK) SMA Kelas X. Diklabio: Jurnal Pendidikan dan Pembelajaran Biologi, 5(2), 10. https://doi.org/10.33369/diklabio.5.2.147-156

Ulfah, M. (2012). Optimalisasi Hasil Belajar IPA Tentang Sistem Gerak Pada Manusia Melalui Metode Diskusi Dengan Tehnik Pembelajaran Tutor Sebaya. 3(1), 6.

Warningsih. (2019). Pengembangan Media Pembelajaran TTS pada Materi Redoks Kelas X SMA.

Wirani, N. D. (2018). Pengembangan Alat Evaluasi Berbantu Media Teka-Teki Silang Pada Mata Pelajaran Marketing Kompetensi Dasar Menerapkan Promosi Produk Di SMK Ketintang. Jurnal Pendidikan Tata Niaga (JPTN), 06(04). 